\title{
FEATURES ON SALE IN DUAL-USE ITEMS
}

\author{
Vasile DINU *, Cristina LAZAR **, Ion-Stelian CHIHAI *** \\ * The Bucharest University of Economic Studies, Romania \\ ** "Ovidius" University Constanta, Constanta, Romania \\ *** National Association of Appraisers, EPI-EBM, Suceava, Romania
}

dinu_cbz@yahoo.com, lazarcristinam@yahoo.com, lustexpert1@yahoo.com

\begin{abstract}
This study addresses a very special issue, i.e. the import-export of those products, goods and technology that normally have civilian uses, but which, because of their nature, may also have military applications. In our opinion, the subject is particularly interesting since these products are related to the development and production of weapons of mass destruction. Therefore, we aimed at highlighting the most important aspects of the marketing standards and practices for the control on dual-use items, with reference to the national and international legal systems in the field. We used the latest bibliography, focusing on documentary sources for certain credibility.
\end{abstract}

\section{Keywords: dual-use items, security, export, civil and military, weapons proliferation}

\section{Introduction}

The trade in dual-use items has a significant impact on international security as a whole. Therefore, both the international law and the EU legislation impose strict rules regarding the export of these products; this legislation undergoes periodic and continuous upgrading. The control on the export of these special items involves a commercial method of security control. For this reason, in this article, we address the EU and national (Romanian) regulations underlying the export of dual-use items.

2. The steps followed at the EU level regarding the regulations on the export of dual-use items

Since the 90s, the European Union has raised several legislative concerns on the control on exports in order to fight against the spread of weapons of mass destruction. Regulation (EC) no. 428/2009 establishes a
Community regime on the conditions under which the exports of dual-use products can be performed. The entry into force of the above-mentioned regulation on $27^{\text {th }}$ August 2009 repealed document (EC) no. $1334 / 2000$ that had established a Community regime for the exports of dualuse items and technologies. The Regulation lays down rules for EU control, joint control lists and harmonized policies for their enforcement, representing the legal basis for carrying out export activities [1].

The Regulation governing the control these product based on a number of specifications of international treaties and conventions to which some EU Member States are signatories.

The Regulation defines in Article 2 "the dual-use items" as follows: "dual-use items shall mean items, including software and technology, which can be used for both civil and military purposes, and shall 
include all items which can be used for both non-explosive uses and assisting in any way in the manufacture of nuclear weapons or other nuclear explosive devices" [1]. Also, Article 9 of the Regulation states that "for all other exports for which an authorization is required under this Regulation, such individual, global or general authorization shall be granted by the competent authorities of the Member State where the exporter is established, in order to preserve the balance between the principle of
Community competence and the legitimate concerns of Member States to maintain control over national security issues".

Directory of Regulation (numbering 10), implementing international agreements such as "the Wassenaar Arrangement[2] (WA), the Missile Technology Control Regime [3] (MTCR), the Nuclear Suppliers Group [4] (NSG), the Australia Group [5] $(\mathrm{AG})$, and the Chemical Weapons Convention $[6](\mathrm{CWC}) "$

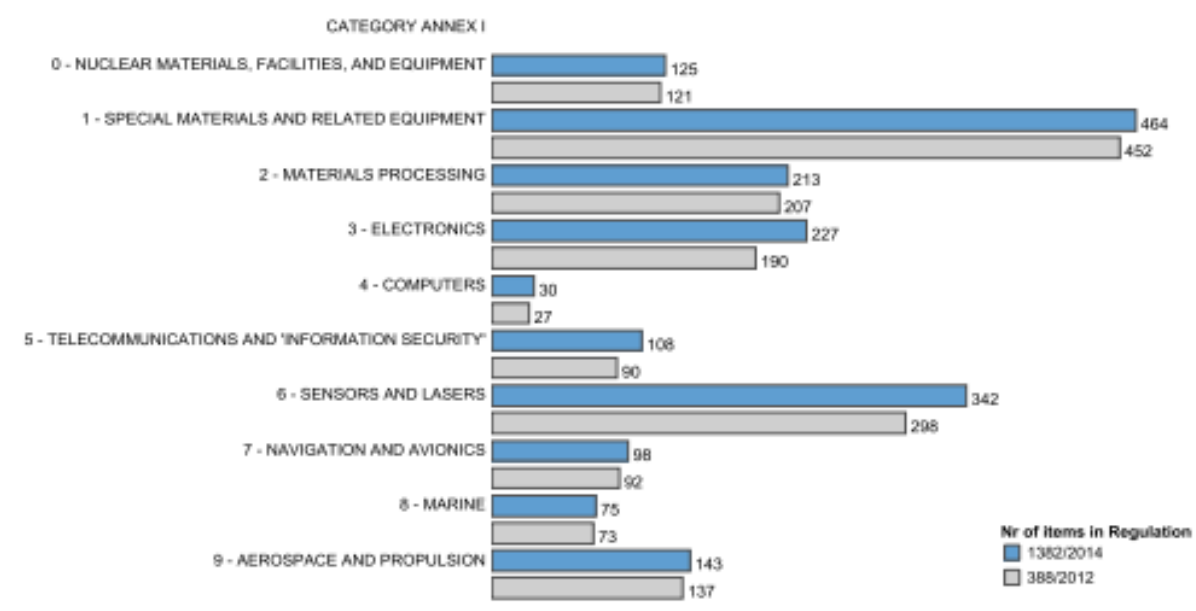

Figure 1: Categories of dual-use items and their number in Annex I to Regulation 1382/2014 (blue bars) compared to Regulation 388/2012 (gray bars).

Source-JRC Scientific and Policy Report, Dual-use trade figures and how they combine, 2015 http://publications.jrc.ec.europa.eu/repository/bitstream/JRC97664/2015.11.19.economicrelevancedu aluse_online_version.pdf

The EU Regulation is subject to the rules set in correlation with the provisions regulated internationally. Internationally, the United Nations Security Council Resolution 1540 underlies the documents governing the control on the trade in dualuse items (2004). In its turn, the Chemical Weapons Convention (1993) also plays an important role in this respect. Last but not least, the Biological Weapons Resolution (1972) also regulates on the above mentioned documents. By their contents regarding the control on the trade in dualuse items, these documents are central to the fight against the proliferation of nuclear, biological or chemical weapons.
On $16^{\text {th }}$ November 2011, there was issued a new Regulation no. 1232/2011, which introduced new EU General Export Authorizations (EUGEAs) for a better control on the export of certain dual-use items (EU001 exports to countries such as New Zealand, Norway, Canada, Switzerland, Australia, Japan, Unites States of America; EU002 exports of certain dualuse items (control lists of Wassenaar Arrangement) to certain destinations; EU003 export after repair/replacement; EU004 temporary export to expositions and fairs; EU005 Telecommunication; EU006 chemicals). 
In 2012, the list of dual-use items was updated by Regulation (EU) no. 388/2012.

It concludes that the current regime of export controls, ensuring a more solid legal and institutional basis, must be updated in order to provide for the necessary modern control tools and capabilities of the European Union in the future [7]. The documents published at the EU level show that this part of foreign trade, i.e. the export of dual-use items, rose to $20 \%$ in 2013 [8].

In 2014, the European Commission proposes "The review of export control policy: ensuring security and competitiveness in a changing world", which highlights four priority axes [9], as follows: (1) Adjusting "to an evolving security environment" and enhancing "the EU contribution to international security"; (2) Promoting "export control convergence and a global level-playing field"; (3)
Developing "an effective and competitive EU export control regime" [9]. (4) Supporting effective and consistent export control implementation and enforcement.

In addition, in 2014, the European Parliament and Council adopted the Regulation (EU) no. 599/2014, which inserted "a delegation of powers to the Commission in order to update the EU checklist in Annex I'. On $12^{\text {th }}$ October 2015, the European Commission issued a document entitled "Update of the EU Control List of Dual Use Items" [10], based on the modifications of the control list that was adopted by international nonproliferation regimes and export control arrangements by the end of 2014. On $12^{\text {th }}$ September 2016, the Commission Delegated Regulation (EU) [11] made another series of amendments to Annex I of Regulation 428/2009.

\section{The impact of the control on dual-use items}

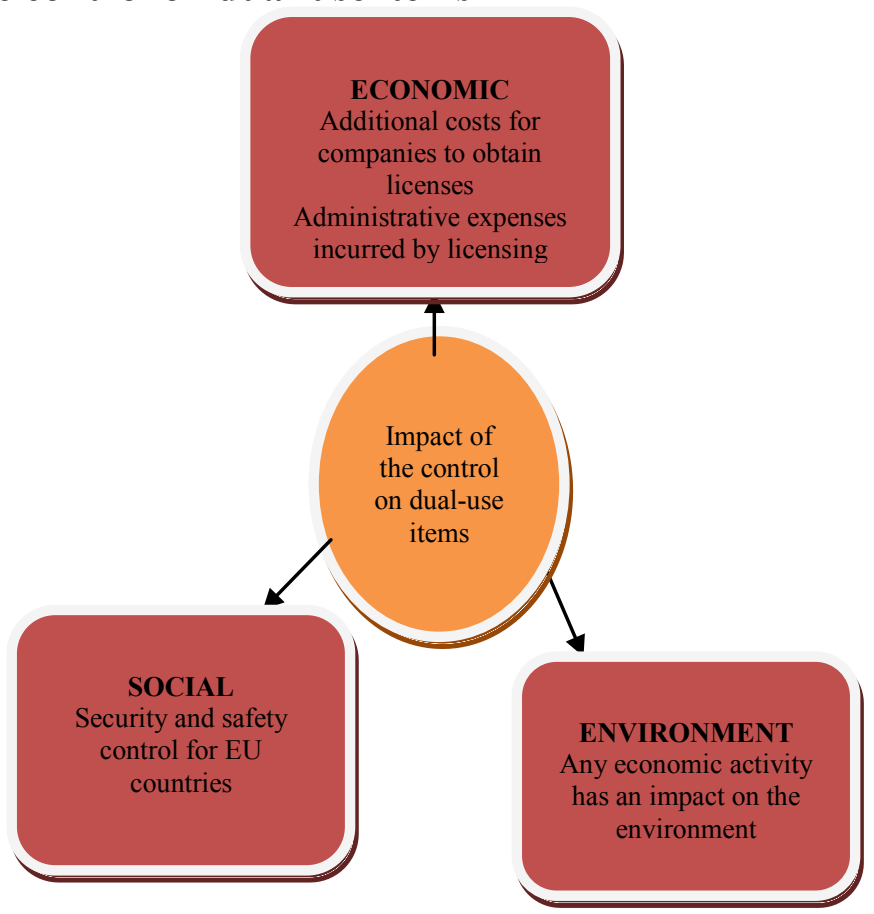

Figure 2 : Drafted by the authors, based on the information published in "Final Report Data and Information collection for UE dual-use export".

\section{Economic}

The general economic size of the control on the export in dual-use items should be seen from a double perspective, i.e. in terms of companies and in terms of state administration. Companies incur additional costs or expenses for the personnel and for the documentation required in order to obtain authorizations. Administrative costs arise from the budgets to be allocated for 
the establishment and operation of export licensing authorities (Article 9 of Regulation no. 428/2009).

\section{Social}

All the above mentioned Regulations involve a control motivated by public safety and by considerations on human rights and fundamental freedoms. The control measures represent an expression of the proliferation of certain negative phenomena that can be amplified by selling items that can be utilized for military goals. The control on the export in dual-use items concerns both citizen safety and public security, provided by the state of legality imposed by the observance of legal provisions.

\section{Environment}

In any economic activity, there is an impact on the environment. This impact can be limited by requiring companies to set up a specialized department (under GEO $195 / 2005)$ in order to manage environmental activities. All the economic activities with a significant environmental impact require a clear coordination, in terms of pollution prevention, mitigation and elimination, as far as possible.

\section{The control on the export in dual-use items - The Case of Romania}

Each EU Member State has the obligation (under Regulation no. 428/2009) to establish a competent national authority. As far as Romania is concerned, the National Authority in the control on the operations with dual-use items is represented by the Ministry of Foreign Affairs, through the Department for Export Controls - ANCEX.

The operations involving dual-use items are subject to approval by the issuance of licenses.

The types of licenses that are issued by ANCEX for operations with dual-use items are:

- the individual export license;

- the global export authorization;

- the national general export authorization;

- the license for intermediation services;
- the transit license.

ANCEX also issues the international import certificate, the delivery control certificate or other equivalent/similar documents issued or certified in accordance with the conditions laid down by the competent authority from the exporter's country.

The legislation and the implementation rules were harmonized with the EU legislation concerning the sale of dual-use items. The amendments and additions from the European legislation were also provided for in the legislation, i.e. Emergency Ordinance no. 119/2010; Government Emergency Ordinance no. 12/11.04.2012, approved by Law no. 35/08.03.2013 amending Government Emergency Ordinance no. 119/2010; Law no. 35/2013 approving Government Emergency Ordinance no. 12/2012 amending Government Emergency Ordinance no. 119/2010; Order no. 914/2012 approving the Methodological Norms for the enforcement of Government Emergency Ordinance no. 119/2010; GD no. $666 / 31.07 .2014$ on the organization and operation of the Council for approving the licensing of the operations with dual-use items and Order no. 358/2016 approving the Methodological Norms for applying the provisions of Regulation (EU) no. $2015 / 1861$ of the Council of $18^{\text {th }}$ October 2015 amending Regulation (EU) no. $267 / 2012$ on the restrictive measures against Iran.

\section{Conclusion}

The international regulations on the trade in dual-use items must ensure a strict control on the movement of these items; however, it must not represent a barrier to free trade. Technological, economic and political change must determine a continuous adaptation of control policies to new challenges.

The measures imposed on the control in the export in dual-use items must ensure a high level of security both nationally, for every country, and globally. 
[1] Regulation (CE) NO. 428/2009

\section{References}

[2] http://www.wassenaar.org/

[3] http://www.mtcr.info/

[4] http://www.nuclearsuppliersgroup.org/en/

[5] http://www.australiagroup.net/en/index.html

[6] http://www.australiagroup.net/en/index.html

[7] Report Of The Commission To The European Parliament And Council on the implementation of Regulation (EC) no. 428/2009 setting up a Community regime for the control of exports, transfer, brokering and transit of dual-use - COM (2013) $710 \mathrm{OF}$ 16 OCTOBER 2013

[8] COM (2013) 710 of 16.10 .2013

[9] $\operatorname{COM(2014)~} 244$ of 24.04.2014 - Export Control Policy Review - Ensuring Security And Competitiveness In A Changing World

[10] Commission Delegated Regulation (EU) 2420/12.10.2015

[11] Commission Delegated Regulation (EU) 1969/12.09.2016 